保筑物理, 5, 129～133 (1970)

\title{
Radiation Protection Experience at The One-Megawatt Pool Reactor THOR and its Affiliated Facilities
}

\author{
P. S. WENG*1 and H. H. LIN*2
}

(Received March 4, 1970)

In an eight-year period of operating THOR and its affiliated facilities, since it went to critical on April 13, 1961, twenty incidents involving more or less serious radiation exposure or reactor hazards were recorded. Some of these incidents are described in this paper. The incidents described here were chosen to give a representative picture of what could be expected in the operation of a reactor facility of similar design and similar purpose under similar operating conditions. The difficulties which exist or have existed in the radiation protection work were reviewed, and the possible solutions were suggested and practiced.

\section{I . INTRODUCTION}

The possession of some unique major facilities such as the $1 \mathrm{MW}$ research nuclear reactor, THOR (Tsing Hua Open-pool Reactor), $3 \mathrm{MeV}$ Van de Graaff accelerator, hot cell of $10,000 \mathrm{Ci}{ }^{60} \mathrm{Co}$ eqnivalent gamma capacity, and the radioisotope production laboratories in which 20 kinds of shortlived isotopes are produced and supplied to domestic users have made National Tsing Hua University, in addition to its regular academic programs, emerge to become a national laboratory and center of studies in the field of nuclear science and engineering. A detailed description of the first research reactor in Taiwan, THOR, is given elsewhere. ${ }^{1)}$ Radiation protection experiences gained with this reactor since it went to critical on April 13, 1961 and with its affiliated facilities will be described hereinafter from the point of view of a health physicist.

\section{UNPLANNED EXPOSURE}

In an eight-year period 20 singificant accidents were recorded at THOR and its affiliated facilities.

\section{*1翁宝山*2林公明}

* Health Physics Section, National Tsing Hua Univ. : Hsinchu, Taiwan, Republic of China
Some of the representative accidents will be described below in the hope that our experience will be shared with health physicists and reactor operators in the operation of similar facilities under similar conditions.

The first accident occurred at 10:20 a. m. on May 2, 1962 at the radioisotope production laboratory while ${ }^{35} \mathrm{~S}$ was being processed. A glass beaker filled with irradiated $\mathrm{KCl}$ was broken when heated with an electric heater. Some of ${ }^{35} S$ spilled on the electric heater and became vaporized. The window of a fume hood in which ${ }^{35} \mathrm{~S}$ was treated had been broken for some days and the radioactive vapor coming out from the hood thus trigged the area monitor. Smear test was taken inside and outside the hood; the result indicated the hood was contaminated with counting rates in the range of $10^{4} \sim 10^{5} \mathrm{cpm}$. The decontamination work took 5 people working for a full day.

On August 9, 1962 another ${ }^{85}$ S contamination occurred at the same place due to poor encapsulation while irradiated in the irradiation basket around the reactor core. The irradiated sample was wrapped with a piece of polyvinyl chloride and then encapsulated in an aluminum can. When the aluminum can was opened in the hood, water was found in the can. The polyvinyl chloride 
wrapper had already been broken; some of the ${ }^{35} \mathrm{~S}$ fell on the floor of the hood. A contamination of $10^{4} \sim 10^{5} \mathrm{cpm}$ was detected in the hood, floor, and the right hand sleeve of the experimenter.

During August 13 till September 8 in 1962 two film badges had the records of $3,440 \mathrm{mrad}$ and $564 \mathrm{mrad}$ respectively due to betas alone. The inquiry of the badge holders revealed the fact that they did repair a broken ion exchange column used for ${ }^{85} \mathrm{~S}$ treatment inside a hood on August 31.

One experimenter irradiated molybdenum in beam port $W-1$, while other experimenter irradiated cobalt in beam port W-2. After irradiation these two samples were stored temporarily in a lead shield that was located in the reactor bay. Warning sign was attached to each sample respectively on March 5, 1963. However, one of the two experimenters took cobolt for molybdenum on March 13. When he opened the lead container, he realized the sample was wrong but had received some external exposure while examining the sam. ple.

On September 14, $1964{ }^{82} \mathrm{Br}$ was sprayed in the isotope production laboratory while being shaken due to machanical failure of the shaker. At the same time next door the fume hood was contam. inated with ${ }^{82} \mathrm{Br}$ when the irradiated sample was opened for treatment due to the malfunction of the opening tool.

A dose rate of $5,000 \mathrm{mR} / \mathrm{hr}$ was detected in the reactor bay when the reactor operators opened the shutter of beam port E-2 on January 27, 1965. An indication light above the beam port was supposed to be observed when the shutter was opened in order to assure that the reactor core had already been removed from the high-power pool section to the low-power section. The reactor operators presumed the electric circuits for the light had been out of order.

The first accident in the hot cell happened on August 9, 1965 when ${ }^{60} \mathrm{Co}$ rods were re-distributed and packed. The hot cell was badly contaminated with ${ }^{60} \mathrm{Co}$ powder, and four persons involved received more or less over exposure ranging from 110 to 920 mrem whole body irradiation.

The routine urinalysis during September 22 through 24,1965 revealed that one of the urine samples reached a counting rate of $2110 \mathrm{cpm} / 250$ $\mathrm{ml}$ urine while the background counting rate was $1 \mathrm{cpm}$. The isotope production laboratory people tried to improve the 131I production process by means of mechanical hands in a junior cave. However, the mechanical hands did not function properly and the off-gas system of the fume hood was not working; the handling of ${ }^{131}$ I had thus to rely on direct manipulation of the experimeter without adequate shielding and remote control.

On December 2, 1965 one irradiated telluric acid sample was electrolyzed and adsorbed by platinium foil during ${ }^{131}$ I production process. Next morning the telluric acid was found leaking out due to a crack of the electrolysis cell. The contaminated area inside the junior cave where the electrolysis cell was located reached a dose rate of $600 \mathrm{mR} / \mathrm{hr}$, even outside the lead shield the dose rate was $100 \mathrm{mR} / \mathrm{hr}$. The isotope production personnel proceeded to do the decontamination work immediately for 40 minutes with a result of whole body irradiation 70 mrem, hand irradiation $140 \mathrm{mrem}$ (gamma) and $75 \mathrm{mrem}$ (beta). The urinalysis revealed that he had received an internal exposure of $2090 \mathrm{cpm} / 250 \mathrm{ml}$ urine on December 4 and $1240 \mathrm{cpm} / 250 \mathrm{ml}$ urine on December 8 , while the background reading was $1 \mathrm{cpm}$

The break of a plastic vial in the pneumatic tube caused an unexpected accident on December 27, 1966. Gold foil was encapsulated in a plastic vial and sent into the pneumatic tube for fourhour irradiation. After being irradiated, the vial did not come out to the rabbit station. The reactor operator suspected that this vial should have been stuck somewhere, so he sent in another vial in order to force the first vial out from the pneumatic tube. However, it did not work at all. The reactor was shutdown on December 19. The pueumatic tube system was throughly checked and finally the blower for the pneumatic tube was disassembled; a few pieces of vial fragments were found but not the gold foil. One end of a vial was taped with adhesive tape (adhesive side out) and it was led through the pneumatic tube again and the gold foil stuck to the tape and came out with the vial. During this search for gold foil and broken vial, all people involved were exposed more or less to radiation.

Over exposure was recorded while working in an environment without proper shielding. One happened on February 28, 1967 when ${ }^{50} \mathrm{Fe}$ was processed. The experimenter received $2,810 \mathrm{mrem}$ (gamma) and $190 \mathrm{mrem}$ (beta) whole body irradiation. Later on April 6 and 7, one worker 
received $3,2 j 0 \mathrm{mrem}$ (gamma) and $190 \mathrm{mrem}$ (beta) while repairing a ${ }^{60} \mathrm{Co}$ radiography equipment without notifying the health physics man.

The internal exposure often happened to ${ }^{131} \mathrm{I}$ production people due to the volatility of ${ }^{181}$ I itself. On April 26, 1967 two newly hired workers electrolyzed ${ }^{131} \mathrm{I}$ outside the hood instead of inside the hood and the air in the laboratory was contaminated.

Another accident involved ${ }^{131}$ I occurred on August 5, 1967 in the reactor bay. Some irradiated telluric acid powder fell in the bay area while it was taken out from the beam port due to the falling of its capsule cape. A dose rate of $\mathbf{5 0 0}$ $\mathrm{mR} / \mathrm{hr}$ was recorded in the bay area. Slight internal and external exposure were received by the decontamination group.

A whole body irradiation of 8,800 mrem was received overnight by a graduate student who used a $270 \mathrm{Ci}{ }^{\circ 0} \mathrm{Co}$ source for his thesis experiment. $\mathrm{He}$ entered the hot cell without putting the ${ }^{80} \mathrm{Co}$ source into a lead container first bscause he was tired and weary for working late till $3 \mathrm{a} . \mathrm{m}$. in the morning.

The very recent accident occurred on July 25 , 1969 when an untrained worker tried to use the manipulators to hoist a $403 \mathrm{Ci}{ }^{60} \mathrm{Co}$ source from a lead container in the hot cell. The door of the hot cell was opened but shielded with lead bricks and concrete blocks with an opening that would let the gamma beam to come out for an experiment set-up. The source suddenly fell off and was out of sight. It caused an environment of $2 \sim 3$ $\mathrm{mR} / \mathrm{hr}$ exiending to most of the isotope production laboratories. Fortunately it was close to $9: 30 \mathrm{p.m}$. and no one stayed late in the laboratories. Six people from the Health Physics Section were called immediately to add more shielding material to and around the opening and to reduce the dose rate to a permissible level for the nearby labora. tories. All people who worked for putting up shielding received some external exposure that night. The source was located next morning and was put back inside the lead container.

The last incident of 1969 happened in the Modern Physics Laboratory where two seniors from Physics Department received 10 rems each on October 12 while they were engaged in an experiment on $\mathrm{X}$-ray radiography. At the same time the laboratory next door was contaminated with ${ }^{32} \mathrm{P}$.

\section{PROBLEMS}

During this eight year period the accidents did occur regardless of the strict rules and regulations that have been imposed on the ionization radiation workers. Some particular and unique problems remain unsolved in a developing country engaging in the atomic energy work. These problems have been reviewed and analyzed by Borthwick ${ }^{2}$. As the field operating health physicists in a nuclear science center and national laboratory, we would like to take a more perspective view on the existing radiation protection problems of our own.

1. Budgetary Limitations

Tsing Hua is an educational institution but undertakes the duty of a national laboratory concurrently. Within the frame of limited budget available for atomic energy development, only a few per cent of budget is available for radiation protection. It is not easy for a health physicist to achieve international accepted standards of safety under these circumstances.

2. Manpower

It is a fact that there is an acute shortage of scientific manpower in most developing countries. Recently the brain drain phenomenon makes this problem more serious. Radiation protection is a branch of science that most people do not appreciate its importance and existence. It is thus difficult to attract top graduates of college or technical school to enter this field.

3. Facilities and Equipment

From the accidents mentioned above one can easily find that some of the accidents were attributed to the poor quality of isotope handling tools, chemicals, containers, and glassware. The delays and difficulties in the provision of laboratory space and essential equipment have naturally affected the radiation protection work.

\section{Technical Assistance and Advice}

In Far East contries the development of atomic energy is similar and almost the same except Japan. The regional cooperation would not be of much help as far as technical assistance or advice is concerned. The International Atomic Energy Agency (IAEA) is virtually the only source to get technical assistance. However, IAEA's resources are not unlimited. The radiation protection man will have to explore other possibilities for assistance. It is by no means 
easy.

5. Language and Information

The bulk of the health physics iuformation is written in English, a little is in Japanese ; the effect of this is principally noticeable for the junior radiation protection personnel. They find literature studies difficult and their ability to work on their own is handicapped. Even a health physicist with advanced degree will feel isolated not being accessed to the health physics information in a developing country.

6. Climate

The prolonged periods of high humidities at high temperature which exist on a semi-tropical island rapidly spoil unprotected electronic equipment. Tube characteristics change, insulators deteriorate through moisture absorption and chemical change, and damaging fungus even appears at vital places.

\section{Training}

The lack of experinece as operating health physicists presents obvious difficulties. No appropriate textbook or reference book on radiation protection written in our own language presents another problem. The newly recurited staff with science or technology background are taught and trained in the laboratories as one kind of on-the-job training. After working for two years, they may be sent to study abroad for an advanced degree or on-the-job training. However, the lack of scientific manpower and the rapid development of peaceful uses of atomic energy in Taiwan have made the training not fast and sufficient enough to meet the requirement.

\section{POSSIBLE SOLUTIONS}

Our domestic problems suggest profitable lines of research and development and lead to investigation on some particular areas. We have attempted to review the problems being faced and have seeked the possible solutions as listed below.

1. Health Physics Research

Health physics research is an important aspect in every health and safety program even in a situation of shortage of experienced staff and available fund. Only through research the standards of safety at a high level can be maintain. ed. The research program will attract and keep competent people, solve the safety problems, and provide incentive and stimulation to staff. A few topics listed below are appropriate for our health physics man to work on and in fact these subjects are being studied.

a. Study on the adsorption properties of local soils and clays for liquid radioactive waste disposal.

b. Investigation into the design and construction of suitable small incinerators for combustible radioactive wastes.

c. Investigation of the production "Ar in the THOR beam ports.

d. Study on the deposition and accumulation of radionuclides in the enviornments.

\section{Removal of Language Barrier}

Some efforts should be made to translate the basic and necessary documents, texts, literature, and information from foreign language into Chinese. The staff are encouraged to take English or Japanese lessons of their own. The IAEA's Basic Standards for Radiation Protection and Health Physics Addendum-Safe Handling of Radioisotopes have already been translated and next will be the Argonne National Laboratory's Radiation Safety Technician Training Manual. The translation of Plutonium Safety Manual and the Radioactive Contamination of the External Environment are scheduled to be finished by next year.

\section{Training}

One three-credit course on radiation protection is offered to senior and graduate students at Tsing Hua every year. In this course laboratory experiments, field operation, and class instruc. tions receive the same attention. The first two lectures of the following courses-reactor experiment, radiation measurement, modern physics laboratory, nuclear chemistry laboratory-must reserve for health physics lectures. In these two lectures, laboratory rules are emphatically stressed. Every neiv staff member of Health Physics Section should receive a three-month period onthe-job training and attend the radiation protection class or read the assigend texts.

\section{Financial Support}

Our research program has become very active since 1967. In such a short period of time ten seniors and four graduate students have involved in our research activities. We hope the results of our research will not only solve our safety problem, but will also give us an opportunity to ask for financial support from National Science Council and other similar foundations. 
Radiation Protection Experience at the One-megawatt Pool Reactor THOR and its Affiliated Facilities 133

Our first contract with IAEA on radioactive waste treatment was approved in September 1968.

5. Technical Advice

Due to geographical convenience we have attempted to start a cooperation program on health physics with Japan and seeked its tech. nical advice if necessary. The first approach is the exchange of technical personnel, to participate in its Health Physics Society, and to publish some technical papers in Japanese journal. This approach has been quite sucessful so far. The technical advice on plutonium safety and bio-assay was given by Japanese health physics group.

\section{CONCLUSION}

Our experience on radiation protection for a one-MW pool type research reactor and our views and comments on attacking the existing problems are by no means complete. All views expressed in this paper are personal ones which are not necessarily the official views of the University. We feel that through intense research and investigation one can solve many problems on radiation protection in a research reactor facility of a developing country.

\section{REFERENCES}

1. C. H. Cheng; "One and a Half Year's Experience with Tsing Hua Open-pool Reactor (THOR) and its Utilization," IAEA Proceedings of a Study Group Meeting on Utilization of Research Reactors, Bangkok, 17-21 December (1962).

2. R. A. Borthwick; "Problems of Health Physics Development in S. E. Asian Countries," IAEA Regional Study Group Meeting, Manila, 9-12 December (1963).

\section{「会員 の頁」投 稿 案 内}

「保健物理」は会貝皆様の雑誌です。編集委員会で は次のようないくつかのカラムを作って，皆様の寄稿 をお待ちしています。ふるって御投稿下さい。

1. 諸案内などのカラム

文献・アイデを求む，研究会の閒催，琉員等集， その他会員のための案内なと。400字以内。

2. 随想などのカラム

保健物理または関係あることについての随想など写 真などの分を合めて 1,800 字 (刷り上り 1 ベージ) 以内。

3. 新技術などの紹介のカラム 保健物理または関連分野の新しい技術・製品・装置 あるいは用語などの紹介や解説。写真などの分を含 めて 850 字 (刷り上り1/2ベーシ) 以内。

4. 事業所便りのカラム おのおのの大学や事業所などの現況や新しいできこ
との紹介など。写真などを含めて 1,800 字(刷り上り 1 ベージ) 以内。

5. 意見などのカラム

本誌，本会あるいは保健物理全般についての意見や 希望など。850字以内。

原稿送り先 茨城県那珂郡東海村 日本原子力研究所 保健物理安全管理部内，保健物理縓策委員会

于 319-11

原稿 切 每発行月の中貝まで。この頃までに到着し たものはその号に掲載できる見込みです。

原稿用紙 1 行が25字あるいは20字の横春きのもの。 その他 氏名, 勤務先, 速絡先（住所, 電話) を必 ず费いて下さい（意見などのカラムでは誌上医名を認 めます）。氏名等のないものは掲載しませんので御注 時下さい。なお採否は絧集委貝会に一任下さい。 


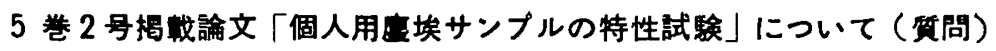

（東芝総研）近藤并

いま私供のところでも，個人エアサンブラを睛入する 計画があって，とのメーカの粒品がよいかと選択にまよ っていた時に，たまたま標嘢の踚文が掍成され，大変に 参考になりました。個人エアサンブラの性能上必要な条 件は，充分な吸引流星がとれて，低抗增大や電源電什の 多少つ変動があっても（刎論なくとも）長時間吸引流国 が不変であることでしょう。この流昷の変動に関与する 因子をバラメータとした実駼テータは大、に私共にとっ て参考となりました。そこで最も決定的な特性をあらわ している Fig. 7 「供給電王と流聂との関係」をみます と, Casella が $5.5 \mathrm{~V}$ 以上で䄪 $2.6 \mathrm{l} / \mathrm{min}$ の一定流量を
しめしておりこれはモータにカバナが装置されている ためであるとして，著者等は高く評佸しておられます。 しかしここで疑問は，この実験が無負荷時のものである ことで，実際の使用状態においては，Casella の流贯は (ミリポア・フィルタ AA) $1.5 \mathrm{l} / \mathrm{min}\left(340 \mathrm{mmH}_{2} \mathrm{O}\right.$ ) であることが同銅文 Fig. 5 でしめされております。そ うだとすれば，実際の使用状態においては，このカバナ の効果はあまり意味がないのではないかと思われます。 論文の実駼データは性能評価上よく理解できましたが， 「実用的である」という結碖には, ちよっと疑䦓が生し ましたので, 御教示頂ければ幸です。

御筫問に対して

御貫問の内容は，

（1）負荷時におけるカバナの奻果

(2) 実用性

の2点を含んでいると考えられます。

そこで, (1) については, Casella の場合についても

Fig. 9 に示す粎な特性図を作っていないため，負荷が との程度增加したら, カバナの効果にどの程度影をも たらすかははっっり断定しかねます。

しかし，以下のことは申し上げられると思います。負 荷が增加するにしたがって，汇紙からタイヤフラムまで の負迁の增加，それによるモーターの消費電力の增加， つまり電池䉓印の降下を引きおこす結果となります。し かし, Casella の場合, Fig. 6 に示す様に負荷が增玑し ても，モーターの消䁈電力が最も低いことおよび Fig.

\section{（原研, 東海）大 㚼勉}

3 の試匼結果から龟池谷畋が他の 2 機種と比較して, 最 も安定していること。以上のことから，負荷が增加する ことによりおこる䉓池電圧の降下は他の 2 種と比較して より遅いと考えられます。したがって，電池電印が 約 $5.5 \mathrm{~V}$ まで，しかもある程度の負荷の籍囲であれば，カ バナを装着してある奻果はあると言えるのではないでし ようか。

(2)の実用的であると判断した理由はここの種のサンフ ラを使用して得られた空﨎中湦度傎をより正確に評価し えることが必要なわけです。そこで, 重要なことはサン ブラの吸引性能が高いことだけでは，実用的であるとは 言えません。その点, Casella の場合は, 他の 2 種と比 較して，(1)で述へた利点をもつことからより実用的であ ろと判断した訳です。 